\title{
Stela OF MENeKH ReCENTLy UnCOVERED \\ AT THE TEMPLE OF KOM OMBO
}

BY

\begin{abstract}
Ahmed Faraman, Sayed Elrekaby \& Mostafa Badawi
Assistant Professor, Department of Egyptology/Faculty of Archaeology, Aswan University, Egypt Inspectors, Kom Ombo Antiquities Area, Ministry of Tourism and Antiquities, Egypt
\end{abstract}

\begin{abstract}
[AR] لوحة منخ المكتشفة حديثا في معبد كوم أمبو الورقة البحثية الحالية هى دراسة تفصيلية للوحة خاصة، اكتشفت أثناء أعمال الحفائر التى اجريت فى معبد كوم أمبو، بالتوازى مع مشروع

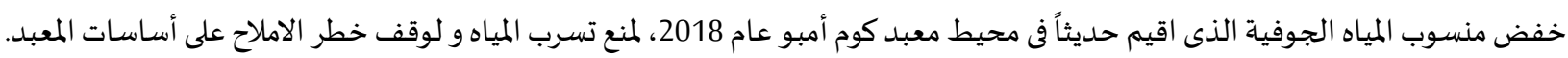

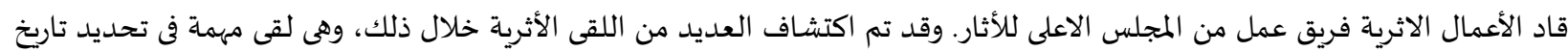

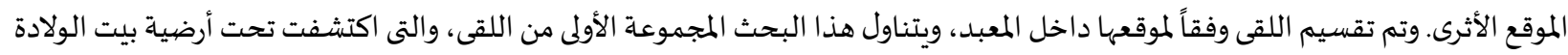
(الماميزى). وتلك المجموعة تتكون من تمثالين لصقر، وتمثال كتلة. والبحث يتناول القطعة الثالثة وهى لوحة خاصة صغيرة الحجم، وصنعت من

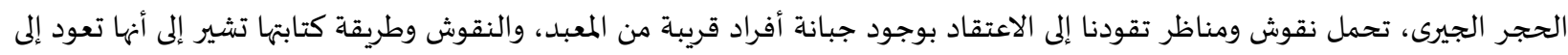
عصر الدولة الحديثة.
\end{abstract}

[EN] This research is a detailed study of a private stela discovered in 2018 during excavations carried out at the temple of Kom Ombo by the Egyptian Supreme Council of Antiquity. The excavations were undertaken in conjunction with the groundwater lowering project within the temple enclosure to prevent the capillary rise of water and salt attack on the temple foundations. Many finds have been uncovered; they are helpful for establishing the chronology of the site. The objects are divided into three groups according to the location where they were uncovered in the temple. This paper deals with a funerary private stela uncovered underneath the paving slabs of the Ptolemaic birth house (Mammisi). It is of small size, made of limestone, bearing both figures and inscriptions, which suggests the existence of a private cemetery nearby the temple. The inscriptions and its paleography suggest that this stela dates to the early New Kingdom.

KEYWORDS: Birth house, stela, groundwater project, archaeological team, private cemetery, chronology, New Kingdom. 


\section{INTRODUCTION}

A stela [FIGURE 1] was discovered in 2018 by the Egyptian team of inspectors of Kom Ombo Antiquities area. It was discovered under the pavement of the birth house (Mammisi) of the Ptolemaic Temple of Kom Ombo during the excavations in conjunction with the project for lowering the groundwater level within the temple enclosure, which in turn was conducted to prevent the capillary rise of water and resulting salt attack on the temple foundations.

\section{DESCRIPTION}

Material: fine limestone [FIGURE 1]

Height: $40 \mathrm{~cm}$. (maximum)

Width: $27 \mathrm{~cm}$.

Depth: $6 \mathrm{~cm}$.

Patina: Medium.

Back: Roughly hammered, some vertical chisel marks.

State of Preservation: quite good, somewhat eroded by natural processes, the upper left quarter missing.

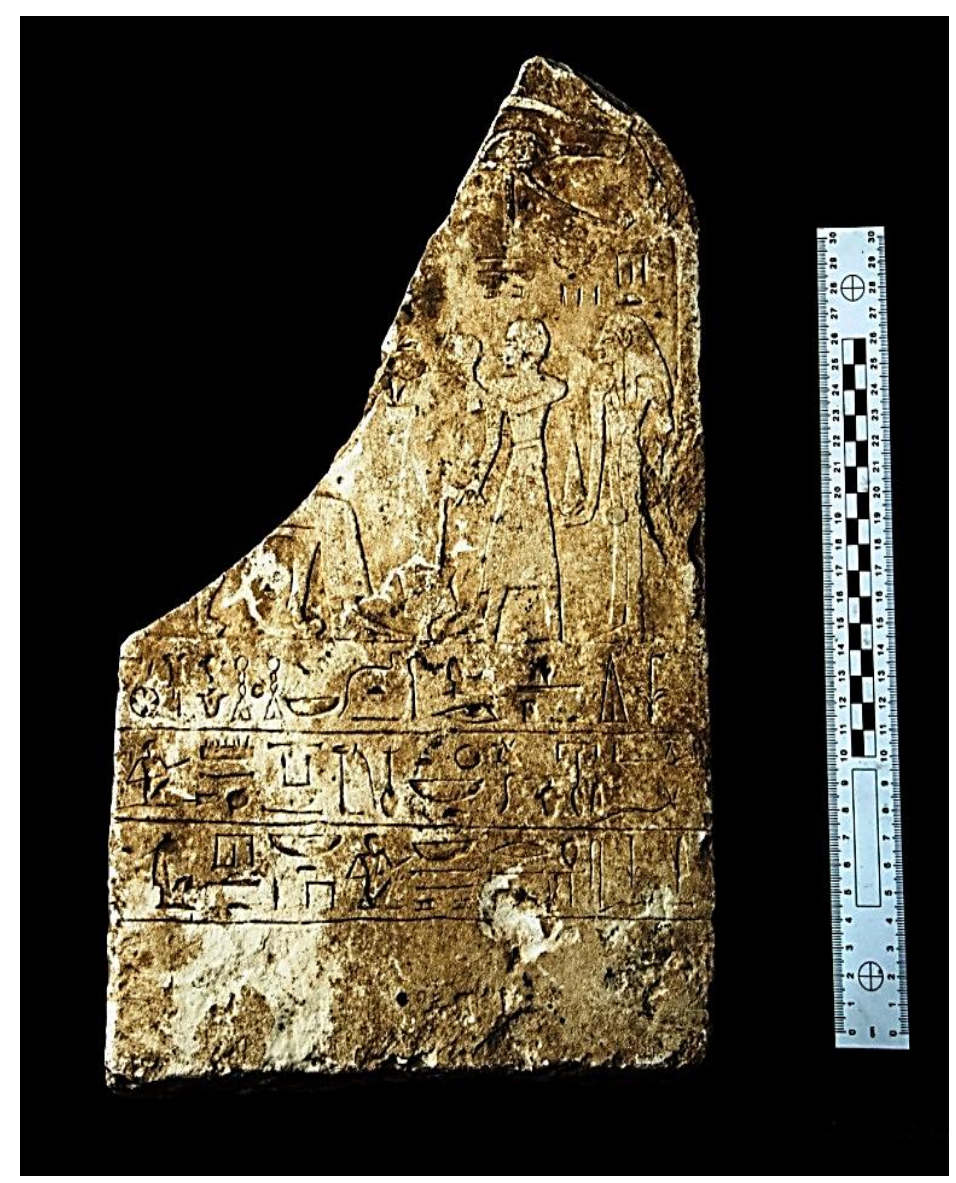

[FIGURE 1]: Funeral Stele of Menekh @ Photographed by Mostafa Badawi 
The study focuses on a fine limestone round-topped funerary stela. It is divided into three sections. The lunette is occupied by a pair of $w \underline{d} 3 t$ - eyes (one is missing now) in raised relief. It is supposed to be one of two symmetrical mirrored $w \underline{d} 3 t$ - eyes ${ }^{1}$, a typical sign of protection for the deceased, usually depicted on the top of such funeral stelae ${ }^{2}$.

Below the $w \underline{d} 3 t$ - eyes is a scene in low raised relief showing a standing man and a women behind him. The man offers to a seated figure, only partially preserved, to the left. The man is accompanied by the caption "ka priest" «hm- $k 3 »^{3}$. His name $(N b) t 3 w y$ is recorded above his head. He pours a libation from a round-bottom vessel with his right hand onto a low offering table, while his left hand elevates an offering of a fowl and a round bread loaf on a small stand.

He is followed by a lady named: $h d t$, she has the title: $n b t$ pr «mistress of the house», who is supposed to be his wife. ${ }^{4}$ She holds a triangular loaf in her right hand, which reads: di, meaning give or offer ${ }^{5}$.

To the left is a seated figure. The upper part of his body is missing. It is supposed to be the deceased, owner of this stela. He is seated on a lion-legged chair, used by highranking people and wearing a long tight cloak. His name, $M n h{ }^{6}{ }^{6}$ is given in the offering formula in the lower register.

The lowest register has three lines of hieroglyphic text.

\section{Text [FIGURE 2]}

The upper part of the stela is occupied by one of the original two $W \underline{d} 3 t$ eyes with text ptr nfrw "seeing the splendor". The standing male figure is surmounted by a

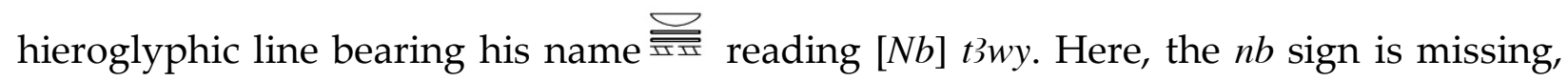
although it is given in the text below. The female figure is surmounted by her name and title: 造 $n b t$ pr hdt

The lower register of the stela has three horizontal lines of hieroglyphic text, running as follows:

\footnotetext{
${ }^{3}$ ERMAN \& GRAPOW, (EDS.): Wb. 3, 90; FAULKNER 1991: 14; DOXEY 2001: 71; LESKO 2002: 310.

${ }^{4}$ The Title $n b t p r$ was attributed only to the married ladies since the Middle Kingdom. ERMAN, \& GRAPOW, (EDS.): Wb, 2: 232; WARD 1986: 8; FEUCHT 2001: 503; AL-CAYEDI 2006: 285- 286.

5 GARDINER 1971: 533; WILFONG 2001: 342; TYLDESLEY 2006: 12-13.

${ }^{6}$ RANKE, $P N 1,153.3$

7 The word ptr was written with the two eyes during the Middle Kingdom, and appeared again during the Ramesside period. KRI, 5, 51, Urk 1794: vol.4, 14; FAULKNER 1991: 96; LESKO 2002: 159.
} 


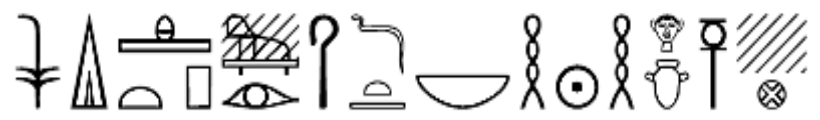

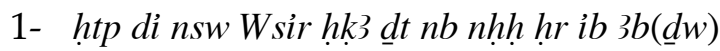

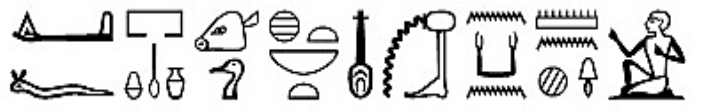

2- di.fprt hrw t hnkt $k 3 w$ 3bdw ht nbt nfrt we $b(t) n k 3 n M n h$

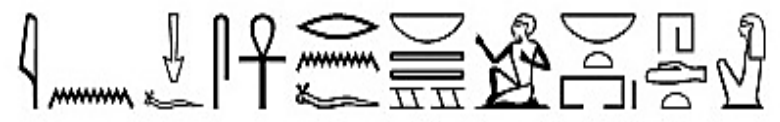

3- in sn.f s'nh rn.f Nb-t3wy nbt pr Hdt

1- An offering (which) the King gives (to) Osiris, Ruler of Eternity, Lord of Perpetuity, who is in Abydos.

2- That he may give a voice of offerings consisting of bread, beer, ox, fowl, (and) every good (and) pure thing, for the $k 3$ of Menekh.

2- It is his son, Neb-tawy who causes his name to live, (and the) lady of the house Hedet.

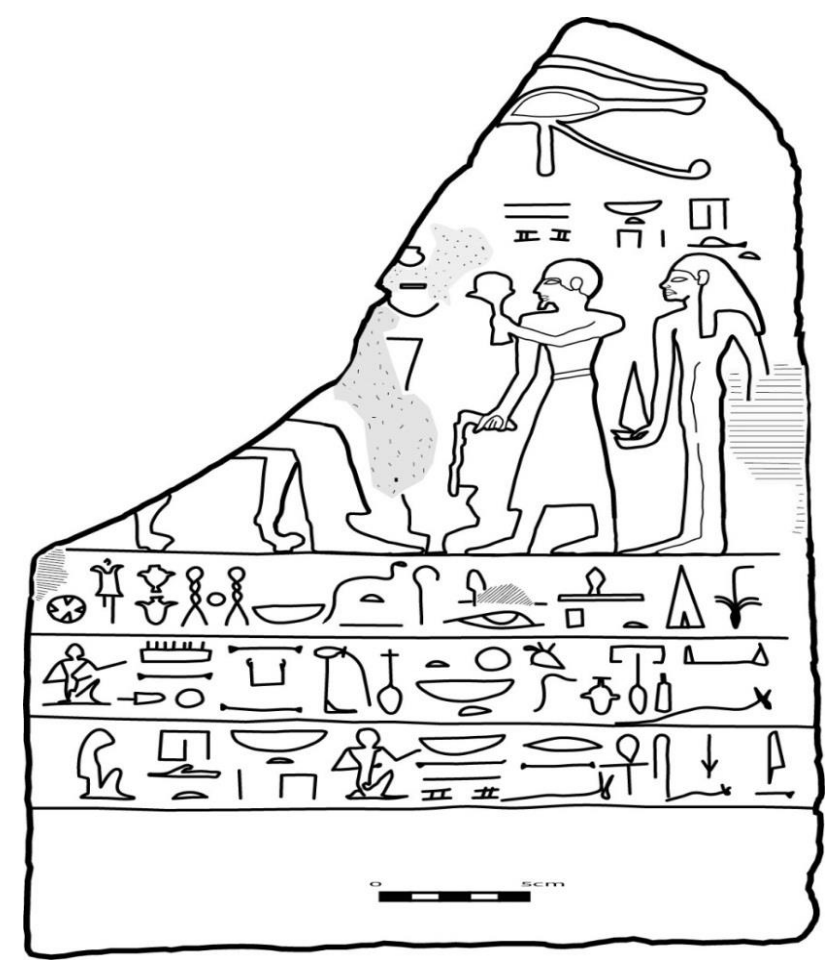

[FIGURE 2]: Funeral Stele of Menekh @ Facsimile by Sayed Elrekaby 


\section{COMMENTARY}

The text reproduced on this stela includes common formulae that suggests it came from a private funeral cult-center, perhaps near the temple where cults had been performed by the deceased's eldest son, or a soul servant priest, called $\mathrm{hm} k 3^{8}$. where a lot of funeral stelae were scattered and reused as part of the foundations of the actual temple.

The above suggestion is supported by finding reused blocks with the name of Thutmose III, Ramsses II and Ramsses III in the temple ${ }^{9}$. They were found incised on sandstone blocks reused in the building of the Ptolemaic birth house and the front quay. These blocks may be from the New Kingdom temple that stood on the site.

The writing of the htp-di-nsw formula is typical of the Eighteenth Dynasty onward ${ }^{10}$. $h k 3 \underline{d} d t, n b n h \underline{h}$ and $n b 3 b \underline{d} w$ are among the common epithets distinguishing Osiris ${ }^{11}$. The sacred name of Osiris is written in a later form with the portable chair, which appeared at the end of the Middle Kingdom ${ }^{12}$.

The text is reproduced in a precise cursive hieroglyphic calligraphy, manifested in many cursive signs, such as: $n, f$ and $w^{\complement} b$, the ripples have entirely disappeared and it could be identified throughout the context, typical of the New Kingdom ${ }^{13}$.

The personal names suggest a date to this stela, which lies within the Middle, or the New Kingdoms ${ }^{14}$. According to the arrangement of the scenes with regard to the texts, it is supposed to date this stela to the first half of the Eighteenth Dynasty, ${ }^{15}$. It confirms a preceding New Kingdom necropolis at Kom Ombo, before the present Ptolemaic temple was erected on the same spot.

\footnotetext{
${ }^{8}$ GARDINER 1971: 170 - 173; COLLIER 1998: 35- 36.

${ }^{9}$ PM 6, 199.

10 SMITHER 1939: 34-37.

${ }^{11}$ BUDGE 1898: 321, 322; HART 2005: 118.

12 Budge 1914: PL. 19, 44; STEWART 1916: PL. 14:4; Urk vol.4, 77, 209; BENNETT 1941: 78.

13 FISCHER 1999: 10-11.

14 RANKE 1935: 153:3, 186: 22- 23; 231: 19, 21.

15 STEWART 1916: 256; HÖLZL 2001: 320-322.
} 


\section{CONCLUSION}

This stela, together with the adjacent findings, discovered may have been it could be assumed that it has been part of the adjustment to the birth house foundations, as the Nile inundation affected harmfully the temple bases. Along with the other findings, uncovered during excavation works, it could be concluded that earlier structures had been dismantled and reused as part of the foundations of the actual temple.

Utilizing the artistic criteria of the stela discussed above, along with the depth of the spot in which it was uncovered, the existence of an intensive New Kingdom cult center could be confirmed, attached to the local god Sobek, appended with a necropolis in the neighboring area. It also confirms the existence of New Kingdom buildings prior to the standing Ptolemaic temple. The earlier temple fell into pieces and its blocks were reused in the foundations of the Ptolemaic temple complex.

The writer and the archaeological team recommend doing a comprehensive excavation in the temple enclosure and the neighboring areas to make further discoveries that might reveal more about the earlier history of the ancient city of Kom Ombo and its temple. 


\section{Ahmed Faraman, Sayed Elrekaby \& Mostafa Badawi}

\section{BIBLIOGRAPHY}

AL-cAYEDI, A.: Index of Egyptian Administrative, Religious and Military Titles of the New Kingdom, Ismailia (Obelisk Publications) 2006.

ANDREWS, C.: «Amulets» in The Oxford Encyclopedia of Ancient Egypt, vol.1, edited by REDFORD, Oxford (Oxford University Press) 2001.

BENNETT, C.: «Growth of the htp- di- nsw Formula in the Middle Kingdom», JEA 27, 1941, 77- 82.

BUDGE, W.: Hieroglyphic Texts from Egyptian Stelae in the British Museum, vol.2, London (Oxford University Press) 1912

BUDGE, W.: Hieroglyphic Texts from Egyptian Stelae in the British Museum, vol.3, London (Oxford University Press) 1912

BUDGE, W.: Hieroglyphic Texts from Egyptian Stelae in the British Museum, vol.5, London (Oxford University Press) 1914

BUDGE, W.: The Book of the Dead, London (Kegan Paul, Trench, Trübner \& Co. LtD.) 1898.

COLLIER, M. \& Manley, B.: How to Read Egyptian Hieroglyphic, Los Angeles (University of California Press) 1998.

DOXEY, D.: «Priesthood», in the Oxford Encyclopedia of Ancient Egypt, vol.3, edited by REDFORD, Oxford (Oxford University Press) 2001.

ERMAN, A. \& GRAPOW, H. (eds.): Wörterbuch der äegyptischen Sprache, I-V, Leipzig (J. Hinrichs) 1926 1931.

FAULKNER, R.: A Concise Dictionary of Middle Egyptian, Oxford (Butler \& Tanner Ltd.) 1991.

FEUCHT, E.: «Family», in The Oxford Encyclopedia of Ancient Egypt, vol.1, edited by REDFORD, Oxford (Oxford University Press) 2001.

FISCHER, H.: Ancient Egyptian Calligraphy, 4th ed., New York (the Metropolitan Museum of Art) 1999.

GARDINER, A.: «A Stele from the Early Eighteenth Dynasty from Thebes», JEA 3/4, 1916, 256- 257.

GARDINER, A.: Egyptian Grammar, 3 ${ }^{\text {rd }}$ ed., Oxford (Cambridge University Press) 1971.

HART, G.: The Routledge Dictionary of Egyptian Gods and Goddesses, 2nd ed., London (Taylor \& Francis Group) 2005.

HÖLZL, R.: «Stelae», The Oxford Encyclopedia of Ancient Egypt, vol.3, edited by REDFORD, Oxford (Oxford University Press) 2001

KITCHEN, K.: Ramisside Inscriptions, vol.5, Oxford (B.H. Blackwell Ltd.) 1990 [= KRI 5].

LESKO, L.: A Dictionary of Late Egyptian, vol.1, $2^{\text {nd }}$ ed., United States (Fall River Modern Printing Co.) 2002.

LESKO, L.: A Dictionary of Late Egyptian, vol.2, $2^{\text {nd }}$ ed., United States (Fall River Modern Printing Co.) 2004

MILLER, P.: «A Family Stela in the University Museum, Philadelphia», JEA 23, 1937, 1- 6.

PINCH, G.: Magic in Ancient Egypt, London (British Museum Press) 1994.

PORTER, B. \& MOSS, R.: Topographical Bibliography of Ancient Egyptian Hieroglyphic Texts, Reliefs and Paintings, VI, Oxford (Oxford University Press) 1991 [= PM 6].

RANKE, H.: Die ägyptischen Personennamen, vol.1, Glückstadt (J.J. Augustin) 1935. 
REMLER, P.: Egyptian Mythology A to Z, New York (Facts on File Inc.) 2010.

SETHE, K.: Urkunden der 18 Dynastie, Leipzig (J.C. Hinriches) 1906 [= urk 4.]

SMITHER, P.: «The Writing of Htp-di-nsw in the Middle and New Kingdoms», JEA 25, 1939, 34- 37.

STEWART, H.: Egyptian Stelae, Reliefs and Paintings from the Petrie Collection, vol.1, London (Aris \& Philipps Ltd.) 1976.

STEWART, H.: Egyptian Stelae, Reliefs and Paintings from the Petrie Collection, vol.8, London (Aris \& Philipps Ltd.) 1976.

TYLDESLEY, J.: Chronicle of the Queens of Egypt, London (Thames \& Hudson Ltd.) 2006.

WARE, W.: Egyptian Artist`s Signature, AJSL 43, N.3, 1927, 185- 207.

WARD, W.: Essays on Feminine Titles of the Middle Kingdom and Related Subjects, Beirut, 1986.

WARD, W.: Index of Egyptian Administrative and Religious Titles of the Middle Kingdom, Beirut (AUB Press) 1982.

WILFONG, T.: «Marriage and Divorce», in The Oxford Encyclopedia of Ancient Egypt, vol.2, edited by REDFORD, Oxford (Oxford University Press) 2001.

WILKINSON, R.: Symbol and Magic in Egyptian Art, London (Thames \& Hudson Ltd.) 1994. 